\title{
The Four Points of the Compass ${ }^{1}$
}

\author{
JAMES ALEXANDER
}

\begin{abstract}
Philosophy has four forms: wonder, faith, doubt and scepticism. These are not separate categories, but separate ideal possibilities. Modern academic philosophy has fallen, for several centuries, into an error: which is the error of supposing that philosophy is only what I call doubt. Philosophy may be doubt: indeed, it is part of my argument that this is undeniably one element of, or one possibility in, philosophy; but doubt is only one of four points of the compass. In this essay I indicate the nature of each point of the compass as it has been found in the history of philosophy.
\end{abstract}

Philosophy is no longer, if it ever was, simply philosophy. It is, and has been since Hegel, a recapitulation of the entirety of the history of philosophy - even if a philosopher resist this truth, as Heidegger did, or ignore it, as Wittgenstein did. Deleuze and Guattari recently suggested that philosophy is 'the coexistence of planes, not the succession of systems' ${ }^{2}$ If this is so, it seems valuable - at a time when philosophy is usually studied from within the middle of its own problems - to attempt to put forward a capacious account of what philosophy is - one which, I argue, can do justice to the varieties of philosophy seen in the entirety of history.

It is worth beginning with what philosophy is not.

Once upon a time all the world spoke a single language and used the same words. As men journeyed in the east, they came upon a plain in the land of Shinar and settled there. They said to one another, 'Come, let us make bricks and bake them hard'; they used bricks for stone and bitumen for mortar. 'Come', they said, 'let us build ourselves a city and a tower with its top in the heavens, and make a name for ourselves; or we shall be dispersed all over the earth.' 'Then the LORD came down to see the city and tower which mortal men had built, and he said, 'Here

1 This essay, written in Downing College, Cambridge in April 2011, is indebted to the writings cited below, but perhaps especially to the writings of D.C. Stove and S.R.L. Clark. They have suggested to me that breadth is still possible in modern philosophy - something I had begun to doubt.

2 Gilles Deleuze and Felix Guattari, What is Philosophy? trans. Hugh Tomlinson and Graham Burchell (New York: Columbia University Press, 1994), 59. 


\section{James Alexander}

they are, one people with a single language, and now they have started to do this; henceforward nothing they have a mind to do will be beyond their reach. Come, let us go down there and confuse their speech, so that they will not understand what they say to one another.' So the LORD dispersed them from there all over the earth, and they left off building the city. That is why it is called Babel, because the LORD there made a babble of the language of all the world; from that place the LORD scattered men all over the face of the earth.' ${ }^{3}$

If I may use elements of this famous story as a parable, here we have the most distinctive elements of the human condition. As Arendt puts it, we labour to achieve the ends which enable us to survive, we work to create artefacts to dignify and decorate our world, and we act in concert in such a way to perpetuate the distinctively human world through 'word and deed'. ${ }^{4}$ She distinguished three sorts of activity: labour (browsing, boiling, baking, burning etc), work (building etc) and action (babbling). Throughout this essay I will refer to 'browsing, building and babbling' to express the entirety of this vita activa. I associate all of them with Babel.

Philosophy is the attempt to avoid the fate of Babel. ${ }^{5}$ God scattered men all over the earth; and so all of the earth became a Babel. Throughout history some of us have used a compass to indicate the way out of Babel. This compass is called philosophy, for want of a better word, and it has four points.

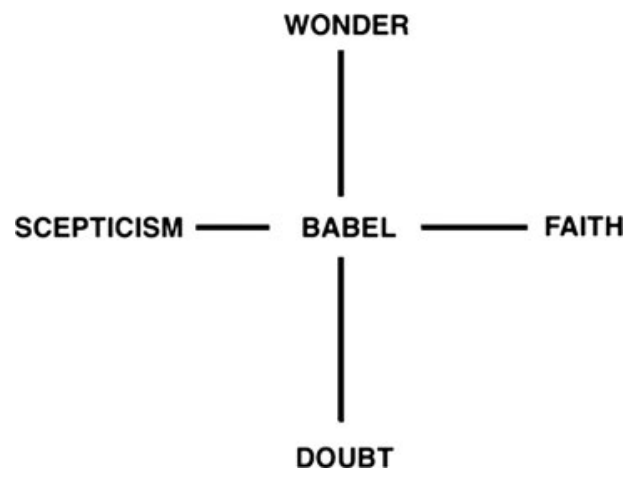

3 Gen. 11.1-9 (New English Bible).

4 Hannah Arendt, The Human Condition (Chicago, 1958).

5 Oakeshott characterised philosophy as 'perhaps the only complete escape there is'. See Michael Oakeshott, Experience and Its Modes (Cambridge: Cambridge University Press, 1933), 3. 
In Babel we are concerned with browsing, building and babbling. In philosophy we are not. The word philosophia is derived from the Socratic or Platonic sense that this Pythagorean word was a better word for the conscientious activity they were concerned with than the word sophia itself. The wisdom of the Sophists was a worldly sort of wisdom, the wisdom of Babel. If sophia was worldly wisdom, a preparation for life, then philosophia was unworldly wisdom, a preparation for death: it somehow involved what should be known by any human who wanted to get beyond the accidental world. The philosopher may always find himself back in Babel. If the philosopher builds too high, or becomes concerned with glory, then he finds he has achieved nothing but his own confusion: he has become one of the scattered humans, browsing, building and babbling over the surface of the earth, banished by God from the one - presumably sacred - language. The ambition of the philosopher is to speak the language of the gods, or to be a god, or to render gods unnecessary.

\section{Wonder}

Wonder is the simplest point of the compass. It is the encounter between a self and the world: but this self is stripped of its inclination to browse, build or babble: it has no purposes, no motives except some strange, apparently 'divine', purpose or motive to see and to know. The world is what is seen and known. But it is seen as if for the first time, as if by a god: it is seen by a human who has no purpose, and has assumed the conscientious posture of already being dead - in the sense of being beyond life - and then sees what this world is. He wants to see it or know it in its truth. And in this first, pure, moment of philosophical experience, he simply sees it for what it is. In a state of wonder, the philosopher abstracts himself from his own concerns. The world is no longer a place of partial adventures but an entire condition, immediate, without a beyond. To attempt to abstract oneself from one's own purposes abstracts the self into a state of wonder, where the world - formerly a world of causes and conditions and consequences - is now simply a vast image or set of images. There is no purpose, no motive, no interest. There is simply what there is. The best way to express this clearly is to say that it is where what seems to be and what is are the same.

Socrates famously suggested that philosophy began in wonder or 'thaumazein'. When Theaeteus confessed he was 'lost in wonder', Socrates said: 'The feeling of wonder shows that you are a 
philosopher, since wonder is the only beginning of philosophy.' 6 Aristotle repeated this view: 'It is through wonder that men now begin and at first began to philosophise; wondering in the first place at obvious perplexities, and then by gradual progression raising questions about the greater matters too. ${ }^{7}$ But perhaps Stove was right to say that 'philosophy typically begins in pseudo-wonder, expressed by asking questions which are really no questions at all.'8 For I am not arguing here that wonder is the origin of philosophy but that wonder is itself a form of philosophy.

It is not original to say so. Heidegger famously attempted to wind back philosophy to where it was before Socrates. ${ }^{9}$ Or where it was for Socrates himself. When he was late on one occasion, Aristodemus explained to friends: 'No, let him alone; it is a habit he has. Occasionally he turns aside, anywhere at random, and there he stands. He will be here presently, I expect. So do not disturb him; let him be. ${ }^{10}$ For some of them the sight of Socrates in a state of wonder was itself a cause of wonder. Plato tells us that the Ionians 'brought out their mattresses and rugs and took their sleep in the cool; thus they wanted to see if he would go on standing all night too'. And, we are told, in a still beautiful image, 'He stood till dawn came and the sun rose; then walked away, after offering a prayer to the Sun.' ${ }^{11}$

Socrates never said what such wonder was like. The Socratic dialogues were, as Stove suggests, exercises in pseudo-wonder rather than in wonder itself. So we have to look elsewhere for a characterisation.

6 Plato, Theaetetus $155 \mathrm{c}-\mathrm{d}$, in the Loeb edition trans. H.N. Fowler (Camb. Mass.: Harvard University Press, 1921), 55.

Aristotle, Metaphysics 982b, in the Loeb edition trans. Hugh Tredennick (Camb. Mass.: Harvard University Press, 1933), 13. See Hannah Arendt, The Life of the Mind (London: Secker and Warburg, 1978), Vol. I, 141.

8 David Stove, The Plato Cult and Other Philosophical Follies (Oxford: Basil Blackwell, 1991), 69.

9 This is the line of thought followed in Mary-Jane Rubinstein, Strange Wonder: The Closure of Metaphysics and the Opening of Awe (New York: Columbia University Press, 2008). See also Kenneth L. Schmitz, The Recovery of Wonder: The New Freedom and the Asceticism of Power (London: Queen's University Press, 2005).

10 Plato, Symposium 175b, in the Loeb edition trans. W.R.M. Lamb (Cambridge, Mass.: Harvard University Press, 1925), 91.

11 Ibid., 220d, in the Loeb, 239. For the two other senses in which Socrates was 'silent' see Alexander Nehemas, 'Voices of Silence: On George Vlastos's Socrates', Virtues of Authenticity: Essays On Plato and Socrates (Princeton, 1999), 83-107. 


\section{The Four Points of the Compass}

Descartes, who was for obvious reasons not particularly interested in wonder, characterised it as

a sudden surprise of the soul which brings it to consider with attention the objects that seem to it unusual and extraordinary. It has two causes: first, an impression in the brain, which represents the object as something unusual and consequently worthy of special consideration; and secondly, a movement of the spirits, which the impression disposes both to flow with great force to the place in the brain where it is located so as to strength and preserve it there, and also to pass into the muscles which serve to keep the sense organs fixed in the same orientation so that they will continue to maintain the impression in the way in which they formed it. ${ }^{12}$

This was meant to be a psychological analysis of wonder. But Heidegger took wonder to be of fundamental existential significance. When we step outside the immediate activity of browsing, building and babbling, and no longer look at the world in order to achieve our ends, but look at it for its, or our, own sake, we experience wonder. Heidegger called this 'curiosity', or Neugier, and said it was 'the tendency towards a peculiar way of letting the world be encountered by us in perception'. ${ }^{13}$ When we are finished with work we rest and see 'the "world" merely as it looks': we allow ourselves to 'be carried along solely by the looks of the world.'14 For Heidegger this wonder gives us 'primordial and genuine truth'. ${ }^{15}$ 'Man alone of all beings, when addressed by the voice of Being, experiences the marvel of all marvels, that what-is $i$ s.' 16 'Truth - and this cannot be the usual sense of truth as opposed to falsity but a unitary truth which is before and beyond truth - cannot take propositional form: on the contrary, it is simply 'the unconcealment and revealment of what-is'. ${ }^{17}$ Heidegger was in his writing concerned with the difficulty we have relating our abstract sense of totality (Sein) to our individual

12 René Descartes, 'The Passions of the Soul', The Philosophical Writings of Descartes trans. John Cottingham et al (Cambridge: Cambridge University Press, 1985-91), Vol. I, 353.

13 Martin Heidegger, Being and Time trans. John MacQuarrie and Edward Robinson (Oxford: Basil Blackwell, 1962), 214.

14 Ibid., 216.

15 Ibid., 215.

16 Martin Heidegger, 'What is Metaphysics?', Existence and Being (London: Vision, 1956), 386.

17 Martin Heidegger, 'On the Essence of 'Truth', Existence and Being, 336. 


\section{James Alexander}

lives in Babel (Dasein). And he called this particular frame of mind Verhaltenheit, a form of wonder which carries with it the meaning of terror and awe. ${ }^{18}$ Needless to say, this is not what I mean by wonder, which is only the apprehension of what is.

Heidegger attempted to say something about the unsayable, but Wittgenstein simply gestured at it. 'There are, indeed, things which cannot be put into words,' he wrote. 'They make themselves manifest. They are what is mystical.' ${ }^{19}$ Or, as he put it in the famous closing line of the Tractatus, 'Wovon man nicht sprechen kann, daruber muss man schweigen' ${ }^{20}$ It is hard not to agree with Williams that something fundamental was expressed here: that, in the twentieth century, some philosophers considered that philosophy might not be the attempt to escape from ignorance, but might be ignorance itself, the speechlessness which comes whenever we encounter whatever is the case. ${ }^{21}$ Then it would be wholly separate from knowledge. 'Deny it as we may, knowledge and wonder counteract one another,' wrote Lawrence. 'So that as knowledge increases, wonder decreases.' 22

If we want to avoid Heideggerian heightening, or Wittgensteinian pathos, then it is possible to characterise wonder as the fundamental form of experience conceived in terms of ideas. If I suppose - as all idealists have - that experience is one, and that there is no difference between what experiences and what is experienced, then the simplest form experience could take would be one in which experience is understood to be what it seems to be. Collingwood in Speculum Mentis offered us the clearest characterisation of this sort of experience: 'aesthetic experience cares nothing for the reality or unreality of its object. It is neither true nor false: it simply ignores the distinction... Its apparent assertions are not real assertions but the very suspension of assertion.' ${ }^{23}$ Wonder is 'question without answer': it makes no distinction between what is imaginary and what is real. The imaginary is

18 Rubinstein, op. cit. note 9, 34.

19 L. Wittgenstein, Tractatus-Logico-Philosophicus trans. D.F. Pears and B.F. McGuinness (London: Routledge and Kegan Paul, 1961), 6.522, 151.

20 Ibid., 7, 151.

21 Bernard Williams, 'Philosophy and the Understanding of Ignorance' (1995), Philosophy as a Humanistic Discipline (Princeton, 2006), 169-79, at 169.

22 D.H. Lawrence, 'Hymns in a Man's Life', Selected Literary Criticism (London: Heinemann, 1956), 7.

23 R.G. Collingwood, Speculum Mentis, or the Map of Knowledge (Oxford: Clarendon Press, 1924), 60. 


\section{The Four Points of the Compass}

the real, the real is the imaginary: what is seen, is. 'It $i s$.' We escape from Babel into Socratic silence. 'The world of imagination is a private world, a world inhabited solely by its author.' And to experience wonder is to have an 'attitude which neither asserts reality, truly or falsely, nor denies it, but merely imagines'. ${ }^{24}$

In wonder there is no truth beyond the world. The philosopher, in a state of wonder, simply sees the world for what it is. What $i$ is what seems to be, and what seems to be is what is. This is Socrates' thaumazein: a form of contemplation, not of Platonic ideas beyond this world, but of the images experienced in this world. Oakeshott thought this was 'all that can, in the end, survive of the Platonic conception of theoria'. ${ }^{25} \mathrm{My}$ own view is that Collingwood was wrong to suggest that this sort of experience is question without answer. If wonder lacks answers, then it necessarily lacks questions. ${ }^{26}$ Questions postulate answers: but wonder is not interested in answers, and therefore is not aware of questions. It is a world of silence. And this is because, in wonder, experiencer and experienced are one, and together constitute experience. Subject and object are transcended, and so unity is experienced.

In a sense, then, wonder is passive. But there is no reason why philosophy has to be active. In faith, too, as we shall see, philosophy is a passivity rather than an activity. This is why the activity which Socrates and Aristotle in their different ways engaged in was not wonder. For philosophy in the usual active sense emerges when we experience the world in wonder, and then ask a question. The question arises because our consciousness suggests to us that what is is not what seems to be: and so we ask the question 'What is if what is is not what it seems to be?' Since questions are not found in wonder, this question is put by Babel. If we hear the question, and attempt to answer it without returning to Babel, then we move to one of the other points of the philosophical compass.

There is, then, a discontinuity between wonder and the other three points of the compass. As soon as we distinguish truth and falsity, or, what is the same thing, as soon as we ask questions, then we see that philosophy is more than mere wonder. Schopenhauer spoke of our 'metaphysical need', the fundamental human need for 'knowledge that goes beyond the possibility of experience, and so beyond

24

25 Ibid., 76.

Oakeshott, 'The Voice of Poetry in the Conversation of Mankind', Rationalism in Politics and Other Essays (London: Methuen, 1962), 220.

26 '...a question [can] only [exist] where an answer exists...' Wittgenstein, op. cit. note 19, 6.51, 149. 
nature of the given phenomenal appearance of things, in order to give information about that by which, in some sense of other, this experience of nature is conditioned'. 27 This need is a consequence of our existing in Babel, among words. It follows what we could call the Parmenidean moment when the wordless recognition of wonder is put into words. The most famous fragment of Parmenides is the line saying: '[It] is, and it cannot be that [it] is not.' ${ }^{28}$ Santayana commented that it is possible to 'contemplate' existence 'without belief' but that "when I assert that such a thing exists I am hypostatizing this datum, placing it in presumptive relations which are not internal to it, and worshipping it as an idol or thing'. ${ }^{29}$ This is the Parmenidean moment, when the veil of experience is torn by utterance, so that the world divides into the word which is uttered and the world which it is uttered of. At this moment philosophy is no longer silent consciousness but a consciousness through words. E pur si muove. And this is why philosophers at the other points of the compass are more likely to return to Babel.

\section{Faith}

Faith is the second point of the compass of philosophy. Babel is a world of many words, of man unsure of his speech, of endless sophistry. But perhaps in this condition we may hear a word which is the truth of the world: a truth which we have sought but not been able to find in our own words. We say, 'It is' and immediately doubt, and ask 'Is it?' and then we may hear a word, 'IT IS'. And this word is certain: and it is certain because it is not human - it has not emerged from the arguments of the sophists - but has come from somewhere else, from the beyond, from something which is beyond or behind the world itself - from the divine. And because this truth is divine, it is certain: it is one, and we have to believe it. This response is faith, and it gives us a form of philosophy in which all thought is understood in relation to one revealed word.

Arthur Schopenhauer, The World as Will and Representation trans. E.F.J. Payne (New York: Dover, 1969), Vol. II, 164.

${ }_{28}$ Quoted in Bernard Williams, 'The Legacy of Greek Philosophy', The Sense of the Past: Essays in The History of Philosophy ed. Myles Burnyeat (Princeton, 2000), 3-48.

${ }_{29}$ George Santayana, Scepticism and Animal Faith: Introduction to a System of Philosophy (London: Constable, 1923), 35. 
As soon as we have a word of all words, a logos which stands opposed to the world, there is a division. And this is why faith is more complicated than wonder: for where wonder is the experience of unity, faith is the experience of division. The word is some unitary truth which, opposed to the world, completes, explains, sanctifies it. As this word is a unity, it is absolutely authoritative: it has authority, and our response to it is belief, or faith: what the Greeks called pistis and the Latins fides. But since the word has come into the world, it divides the world into two. The word comes from beyond, or behind, the world: and our usual word for this is God. The Abrahamic religions - Judaism, Christianity, Islam - have made the most of this understanding, although it is also evident elsewhere, in all other religions and in much philosophy. This problem, which is the problem of faith, is the problem of how to explain the separation of word and world: how to explain the fact that what $i s$ is divided into appearance and reality: that is, into what seems to be and what is - or, as is usually said, what really is.

We can distinguish, perhaps, two sorts of faith. One is relative, the other absolute. The relative form of faith is the sort of faith we find in rational religion, natural religion, and Neoplatonic or Hegelian thought: in which we suppose there is a 'divine' truth which is somehow hidden by but also existing within the world as we experience it. This is a relative sort of faith because it tends to involve elements of doubt: that is, it postulates that there is something about our place within this world which makes it possible for $u s$ to establish the truth which is not the obvious simple truth of experience. It is immanentist. But the other, absolute, form of faith, is the pure form of faith: and it is where there is no dependence on reason at all, only on faith. It is transcendental. Here there is a relation, as Buber put it, not between I and It - where 'It' may be the truth of the world, the One or the Absolute - but between I and Thou. These two forms of faith are what Kierkegaard distinguished as 'religiousness of immanence' and 'paradoxical religiousness' ${ }^{30}$ Others call them religions of reason and revelation. The latter is the pure form of faith - and consequently more difficult to explain.

This form of faith comes to its highest manifestation in the Abrahamic religions. In the Old Testament God's word was first manifest in the covenant (berith) with the Israelites, and established in the law (torah). The Old Testament itself was, as Balthasar

30 Kierkegaard, Concluding Unscientific Postscript to the Philosophical Crumbs trans. Alastair Hannay (Cambridge: Cambridge University Press, 2009), $465 \& 468$. 


\section{James Alexander}

explained, 'history, which convicts man as a sinner and confronts God with the fact of the broken covenant'. ${ }^{31}$ In Christianity and Islam, therefore, the word was spoken for a second time: for Christians as a 'new fact', and for Muslims as a 'new text'. ${ }^{32}$ Christianity claimed that the word of God was not the law but the man who came to fulfil the law. ${ }^{33}$ And Islam claimed that the word of God was a final word of law in the form of the Qu'ran revealed to the Prophet.

Christianity is the more perplexing. For in Christianity the word, the logos, was God himself. 'In the beginning was the word.' The kérygma, proclamation - or didaché, teaching, apokalypseos, revelation, evangelion, gospel - of Christianity was not any of Jesus's words but Jesus himself, the 'word made flesh'. ${ }^{34}$ The word was not an idea but an event: that God loved us, and had shown this love by coming to earth, suffering everything, even crucifixion. ${ }^{35}$ This event required faith, for, as Kierkegaard said, 'the understanding cannot come to know this by itself'. ${ }^{36}$

Hath not God made foolish the wisdom of the world? [wrote Paul] For seeing that in the wisdom of God the world through its wisdom knew not God, it was God's good pleasure through the foolishness of the preaching to save them that believe. Seeing that Jews ask for signs, and Greeks seek after wisdom: but we preach Christ crucified, unto the Jews a stumblingblock, and unto Gentiles foolishness;... God chose the foolish things of the world, that he might put to shame the wise. ${ }^{37}$

And Tertullian claimed, 'Certum, quia impossibile...': 'it is certain, because impossible'. ${ }^{38}$ This is the contradiction which has

31 Hans Urs von Balthasar, The Glory of the Lord: A Theological Aesthetics 1961-7 (Edinburgh: T. \& T. Clark, 1982-91), Vol. VI, 215.

32 Rémi Brague, The Law of God: The Philosophical History of an Idea trans. Lydia Cochrane (Chicago: University of Chicago Press, 2007), 97.

33 See Hebrews 4.12 for 'alive and active', Matthew 5.17-19 for the fulfillment of the law, and John 1.1. for the famous logos doctrine.

34 See Exegetical Dictionary of the New Testament eds. Horst Balz and Gerhard Schneider (T. and T. Clark, 1990), Vol. II, 288-92.

35 Constantine Constantius, Repetition: An Essay in Experimental Psychology 1843 trans. by M.G. Piety in Repetition and Philosophical Crumbs (Oxford: Oxford University Press, 2009), 107.

36 Ibid., 119.

37 Cor. 1.21-27 (King James Version).

38 Tertullian, de carne Christi, 5. See Tertullian's Treatise on the Incarnation ed. Ernest Evans (London: S.P.C.K., 1950), 19. 
accompanied faith down the ages: that the truth of faith is 'something which, for all its incomprehensibility, is still comprehensible'. ${ }^{39}$

The problem of faith is how something not of this world can come into this world. The word divides the world into good and evil, true and false etc. But it raises the problem of how a single, eternal and unchanging God can have a relation to the world. Mc'Taggart argued that if God causes change, and the law of causation is that anything which causes change is itself changed, then a changeless God could not come into the world. 'We must therefore suppose that God causes change without changing.' ${ }^{40}$ For Mc'Taggart this and other contradictions made faith untenable. 'Most people have no right to accept any religion as true' ${ }^{41}$

But this could never be the end of the discussion. For within faith as within scepticism - a contradiction is not a refutation. 'It is absurd,' said 'Tertullian, 'so I believe it.' Williams, when reflecting on Tertullian's claim, commented that there is 'a sort of inherent and necessary incomprehensibility, which seems to be a feature of Christian belief'. He added: 'If the Christian faith is true, it must be partly incomprehensible, but if it is partly incomprehensible, it is difficult to see what it is for it to be true. ${ }^{42}$ Mc'Taggart and Williams came to an impasse because they considered faith from the point of view of doubt. But within faith the contradiction may be embraced. According to Soloviev, 'The truly one is that which does not exclude plurality, but on the contrary produces that plurality within itself and yet is by no means changed by it, but remains what it is, remains one and thereby proves that it is unconditionally one.' 43 Of course, to state a contradiction is not to understand it. But Collingwood saw, as McTaggart did not, that the correct way of understanding faith is to see that it is not expressed in terms of claims such as 'God exists', but in terms of claims such as Credo in unum deum, or 'I believe God exists'. For Collingwood one could never treat 'God exists' as a proposition. ${ }^{44}$

39 Karl Barth, 'Bultmann - An Attempt to Understand Him', Kerygma and Myth: A Theological Debate trans. Reginald H. Fuller (London: S.P.C.K., 1962), 83-132 at 99.

40 J.M.E. McTaggart, Some Dogmas of Religion (London: Edward Arnold, 1906), 194.

41 Ibid., 293.

42 Bernard Williams, 'Tertullian's Paradox' (1955), in op. cit. note 21, $3-21$, at 3,20 .

43 Vladimir Solovyov, Lectures on Godmanhood ed. Peter Zouboff (London: Dennis Dobson, 1948), 133.

$44 \quad$ R.G. Collingwood, An Essay on Metaphysics (Oxford, 1940), 188. 


\section{James Alexander}

The absurdity of Christ crucified - or even of Yahweh or Allah uttering the word of law - can never be overcome through reason. ${ }^{45}$ For this absurdity is the absolute limit of faith, just as logical paradox is for scepticism. Doubt, as we shall see, denies the existence of both absurdity and paradox: it demands consistency, and sees only contradiction, and understanding contradiction as reductio ad absurdum. But faith depends on a word which both can and cannot be understood. If it cannot be understood, we cannot have faith; but if it can be understood, then it can be translated: but it is of the nature of faith - any faith - that it is beyond translation. Collingwood, again, put this most clearly. 'Religion cannot translate itself not because it has no meaning, for it has a very definite meaning, to elicit which is the progressive task of theology and philosophy; but because, although it has a meaning and knows that it has a meaning, it thinks it has expressed this meaning already.' 46 So the word of Christianity is Christ crucified, and - despite Kant, Fichte, Hegel, Schopenhauer, Feuerbach and the rest - this is a word which does not become truer when it is expressed in terms of reason. It has to remain beyond reason in order to be the word it claims to be. ${ }^{47}$

The strength of faith is that it offers certainty, a certainty which doubt seems to fail to establish, and which scepticism denies can ever be established. Theologians sometimes claim that faith is required to support our knowledge of the external world.

That anything exists outside of ourselves and independently of ourselves - that we cannot know, because all that we know (actually), that is to say, all that we experience, exists within us, not outside of us (as our sensations and our thoughts); and what is not within us, but is in its own self, is thereby beyond the limits of our experience and, consequently, outside of our actual knowledge; it can be asserted, thus, only by an act of the spirit which can reach beyond the boundaries of this reality of ours - and it is this act of the spirit which is called faith. ${ }^{48}$

Not even by advocating a 'dual-aspect doctrine of God'. See Keith Ward, Images of Eternity: Concepts of God in Five Religious Traditions (London: Darton, Longman and Todd, 1987), 153-63.

46 Collingwood, op. cit. note 23, 130.

47 For the rejection of the entire tradition of Schleiermacher, Harnack, Ritschl and Troeltsch see Emil Brunner, Revelation and Reason: The Christian Doctrine of Faith and Knowledge (London: S.C.M., 1947).

48 Solovyov, op. cit. note 43, 91. 
MacIntyre thinks many philosophers do not understand what faith involves. Atheists assume 'a theist is someone who believes in just one more being than they do and who therefore has the responsibility for justifying her or his belief in this extra entity'. But atheists have 'misconceived both God and theistic belief in God'. For a theist, God is not an addition to nature; but a ground of nature: nature itself is 'radically incomplete', and requires a 'ground beyond itself' if it is to be intelligible. So it follows that 'the disagreement between atheists and theists is one of those fundamental disagreements that extends to how the disagreement is to be characterised.'49 God is a postulate of this form of philosophy. Whitehead wrote:

God is the ultimate limitation, and this existence is the ultimate irrationality. For no reason can be given for just that limitation which it stands in His nature to impose. God is not concrete, but $\mathrm{He}$ is the ground for concrete actuality. No occasion can be given for the nature of God, because that nature is the ground of rationality. ${ }^{50}$

Clark has gone further by claiming that not only God but also the Trinity and the Incarnation are necessary postulates of reason. If there is truth at all, he claims, then it depends on an absolute truth. $\mathrm{He}$ argues that beyond the finite world there is an infinite and necessary entity, that this entity - God - has to be known by us, and that God had to become human and suffer as Jesus did in order to make faith possible. ${ }^{51}$ Clark's arguments are, interestingly, as MacIntyre's are, for faith rather than from faith. He is very careful, for instance, to say that there is no reason why the mediator needed to be the historical Jesus. ${ }^{52}$ So even here, where there is a maximum of argument, there is in the end an acknowledgement that in faith reason is eventually inevitably dependent on revelation. The God of faith is both the root of every existent thing and one among many.

Both MacIntyre and Clark write as far as they can about revelation in terms of reason - about faith in terms of doubt. But Collingwood

49

Alasdair MacIntyre, God, Philosophy, Universities: A Selective History of the Catholic Philosophical Tradition (London: Continuum, 2009), 47.

50 A.N. Whitehead, Science and the Modern World (Cambridge: Cambridge University Press, 1927), 221-2.

51 Stephen R.L. Clark, God, Religion and Reality (London: S.P.C.K., 1998), viii.

52 Ibid., 118. 
was right. Faith in the end cannot be translated into doubt. This is why it is usually ignored by modern academic philosophers. They trust reason, not revelation. 'The statements made by religion are often false, or at least doubtful,' said Collingwood. 'But religion is committed to asserting them as true. ${ }^{53}$ This is the characteristic voice of doubt, the next point of the compass.

\section{Doubt}

Doubt is logically subsequent to faith. We exist in a world, and experience wonder, which is silent. Words return us to Babel. But if we hear a word which is certain we can avoid Babel by responding to this word of all words with faith. But a further question can arise, which again may return us to Babel, which is how we can know that this word rather than any other is the word of all words. This is the beginning of doubt - the dubium we experience when truth is divided. It leads us to ask the question Russell asked in the first sentence of his Problems of Philosophy: 'Is there any knowledge in the world which is so certain that no reasonable man could doubt it?'54 In faith there is no difference between what I believe and what I know; but when we experience doubt we feel the absolute imperative to distinguish them. And for this we need some sort of certain criterion of truth, a means of demonstration - in short, a method. Doubt is the attempt to establish what can be known by considering every possibility until what cannot be doubted is left as what is certain. It is, then, philosophy at the third point of the compass philosophy as an activity, the human activity, of attempting to establish certainty.

Doubt is a consequence of our hearing differing, contradictory, truths. We hear the truth of Christ crucified, but we then hear the truths of the Torah and the Qur'an, the truths of Buddhism, Brahmanism and Daoism, the truths of Platonism, Aristotelianism, Cynicism, Stoicism, Scepticism, Epicureanism, Thomism, Empiricism, Kantianism, Utilitarianism, Hegelianism, Marxism, Nietzscheanism, Darwinism, Freudianism, Wittgensteinianism, Liberalism, Socialism, Conservativism etc. Here, we may well suppose we have returned to Babel. And this confusion of tongues which is a confusion of truths, of words - is the origin of doubt.

\footnotetext{
53 Collingwood, op. cit. note 23, 130.

54 Bertrand Russell, The Problems of Philosophy (Oxford: Oxford University Press, 1998), 1.
} 
For doubt is not itself the disturbance which results from hearing different words, but the manifest response to this. Newman explained that 'doubt itself is a positive idea, and implies a definite habit of mind, and thereby necessarily involves a system of principles and doctrines all its own.' 55 The most important of these principles is that doubt postulates certainty. 'If you tried to doubt everything', wrote Wittgenstein, 'you would not get as far as doubting everything - the game of doubting itself presupposes certainty.' 56

Doubt submits everything to a human method of rational interrogation. But it also postulates the existence of a certainty more certain than the certainty of faith - a certainty known through demonstration. This is not a divine, given, truth - revealed - but a human, acquired, truth - reasoned, indeed, argued. If there is anything ubiquitous in philosophical doubt it is argument. The dialektike of Plato, the syllogismos of Aristotle, the quaestiones of Aquinas, the méthode of Descartes were all about argument: the idea that one would begin with propositions, which were themselves susceptible of exposure to doubt, and then derive indubitable inferences from them. Most philosophy now is still conducted in the great shadows of these monuments of argument. But it is important to note here that these philosophers were concerned not only with what we might call the absolute certainties of philosophy but with the certainties associated with any successful demonstration. The branch of philosophy called 'natural philosophy' - the sciences associated with what Plato called hypothetical knowledge - has had so much success with a doubtful method, especially in the last five hundred years, that many modern philosophers are only dimly aware that there are other points of the compass.

The are two levels at which doubt seeks certainty: at what we may call the absolute, unconditional, or unhypothetical level, and at the relative, conditional, or hypothetical level. The success of Aristotle, Eratosthenes, Copernicus, Bacon, Galileo, Boyle, Hooke, Watt, Lyell, Darwin, Agassiz and so on - a long list - in the sciences obscures the extent to which certainty is still sought at a higher level: and, importantly, that certainty has to be sought at a higher level if we are to be sure that the certainties of the sciences are certain. The problem goes right back to Socrates. He was executed for leading

55 J.H. Newman, An Essay in Aid of a Grammar of Assent ed. Ian T. Ker (Oxford: Clarendon Press, 1985), 243.

56 Ludwig Wittgenstein, On Certainty ed. G.E.M. Anscombe and G.K. von Wright. (Oxford: Basil Blackwell, 1969, sect. 115, 18e, repeated in sect. $122,18 \mathrm{e}$, sect. $160,23 \mathrm{e}$, sect. $346,44 \mathrm{e}$, sect 354 , 46e. 


\section{James Alexander}

others into doubt. 'It is not from any sureness in myself that I cause others to doubt,' he told Meno. 'It is from being in more doubt than anyone else that I cause doubt in others.' 57 Plato suggested certain models of dialectical method to overcome doubt. The scholars still seem to agree that there were three major sorts of method advocated in his dialogues: i. the early Socratic method of elenchus, of question and answer, that is, taking suggestions and refuting them, a process which usually ended in aporia or impasse - where the problem was to try to establish the idea of something which was to be understood; ii. the method of hypothesis, used from the Meno and Phaedo onwards, in which propositions were laid down about what was to be understood in terms of ideas - a generally deductive and constructive method which ended in discussion of the nature of ideas themselves; and iii. the later method of collection and division, found from the Phaedrus onwards, in which the ideas themselves were classified in terms of various ordering principles. ${ }^{58}$ But in the Republic Plato arranged the different levels of knowledge into a hierarchy and declared that the highest was the sort of knowledge which originates from an anupothetos arché, a non-hypothetical first principle, and therefore is absolutely certain. The next was hypothetical knowledge, that is, knowledge which begins with a hypothesis, and so is never more than relatively certain. Lower was faith, and even lower still was illusion. There was never a problem with hypothetical knowledge, which is the sort of knowledge everyone understands; but Plato never said what unhypothetical knowledge was. All we can assume is that it was some sort of absolute limit or origin. It was possibly the subject of Plato's lecture on the 'One' and the 'Great and Small' which disconcerted Plato's students, including Aristotle, and still disconcerts philosophers now. ${ }^{59}$

What philosophers of doubt since Descartes have sought is a hypothesis which will be as certain as an unhypothesised first principle. Descartes wanted to see if he could 'reject as if absolutely false everything in which [he] could imagine the least doubt, in order to see if [he] was left believing anything that was entirely

57 Plato, Meno 80c-d, in the Loeb edition trans. W.R.M. Lamb (Camb. Mass.: Harvard University Press, 1924), 299.

58 Richard Robinson, Plato's Earlier Dialogues (Ithaca, New York: Cornell UP, 1941), repeated in J.D.G. Evans, A Plato Primer (Durham: Acumen, 2010), 65-83.

59 Although not J.N. Findlay, Plato: The Written and Unwritten Doctrines (London: Routledge and Kegan Paul, 1974). 
indubitable'. ${ }^{60} \mathrm{He}$ was open to the possibility that doubt might make certainty impossible. In the Meditations he said, 'Anything which admits of the slightest doubt I will set aside just as if I had found it to be wholly false; and I will proceed in this way until I recognise something certain, or, if nothing else, until I at least recognise for certain that there is no certainty.' ${ }^{61}$ But, as Williams put it, 'Descartes was not a sceptic.' ${ }^{62} \mathrm{He}$ thought that doubt itself could be elevated into a basis of a certainty which could defeat doubt; for, as he argued, it was impossible to doubt that one doubts. And 'I doubt, therefore I am' was warrant for 'I think, therefore I am'.

If this argument established the self, Descartes unfortunately, as we all know, argued for the certainty of everything else from the existence of God. Although he claimed in the Principles of Philosophy that 'we must first of all lay aside all our preconceived opinions, or at least we must take the greatest care not to put our trust in any of the opinions accepted by us in the past until we have first scrutinised them afresh and confirmed their truth', he also claimed that 'whatever God has revealed to us must be accepted as more certain than anything else' for 'although the light of reason may, with the utmost clarity and evidence, appear to suggest something different, we must still put our entire faith in divine authority rather than in our own judgement'. ${ }^{63}$ His entire philosophical system - his claim that the external world actually exists - depended on what Williams called a 'religious bridge', and collapses immediately if God's existence is believed not to be beyond doubt. ${ }^{64}$ This has been a great problem for doubting philosophy ever since. Until at least Berkeley and possibly as late as Bradley, philosophers found it hard to avoid appealing to God, or some surrogate for God in the form of an 'Absolute', to save doubt from scepticism.

Deduction and induction are an argumentative machinery of formidable power - as the history of mathematics and the sciences since Descartes and Bacon suggests - but it remains as difficult as ever to show why there is any reason to suppose that deduction

60 René Descartes, 'Discourse on the Method', The Philosophical Writings of Descartes, Vol. I, 144.

61 René Descartes, 'Meditations on First Philosophy', The Philosophical Writings of Descartes, Vol. II, 16.

62 Bernard Williams, 'Descartes's Use of Scepticism', in op. cit. note $28,231-45$, at 232 .

63 René Descartes, 'Principles of Philosophy', The Philosophical Writings of Descartes, Vol. I, 221.

64 Bernard Williams, Descartes: The Project of Pure Enquiry (Sussex: Harvester, 1978), 153. 


\section{James Alexander}

generates certainty about what is necessary or why induction generates certainty about what is contingent. In the first half of his life Russell sought certainty in mathematics, but Wittgenstein convinced him that he had found 'tautology' rather than 'truth'. ${ }^{65}$ In the second half of his life he sought certainty about the world, but all he found was a 'probability' which 'approaches indefinitely near to certainty'. ${ }^{66} \mathrm{He}$ objected to scepticism, saying, 'Universal scepticism cannot be refuted, but also cannot be accepted. ${ }^{67}$ But in his last major original work he declared that 'all human knowledge is uncertain, inexact and partial'. 'To this doctrine,' he added, 'we have not found any limitations whatever.' ${ }^{68} \mathrm{He}$ continued to think that the certainties of science have 'a higher degree of probability than anything likely to be achieved in philosophical speculation'. ${ }^{69}$ And he ended his life still claiming - by ignoring Gödel's incompleteness theorem that 'certainty is more likely to be found in mathematics than elsewhere. ${ }^{70}$ All Russell could demonstrate was that certainties are either hypothetical or probable.

Almost everyone since Plato has struggled to indicate how we can achieve anything more than hypothetical certainties through deduction or probable certainties through induction. Some have argued that we cannot have certainty without faith. Newman, for instance, argued that doubt could deliver only hypothetical certainties. He distinguished two types of assent to propositions, 'notional assent' and 'real assent'. Notional assent is the acceptance of an abstract proposition, where we assent to the proposition without assenting to its presuppositions. If we want, we may assent to those presuppositions, by yet another notional assent. Real assent, however, is assent to a proposition, where it is condition of assent that we assent to all of its presuppositions. ${ }^{71}$ In notional assent we move from proposition to proposition, from postulate to postulate, without ever achieving certainty, but in real assent we avoid an infinite regress and achieve certainty. In other words, Newman thought that there was a distinct

65 Bertrand Russell, My Philosophical Development (London: Allen and Unwin, 1959), 210-11.

66 Bertrand Russell, Our Knowledge of the External World: As a Field for Science Method in Philosophy (London: Open Court, 1914), 222.

67 Russell, op. cit. note 65, 207.

68 Bertrand Russell, Human Knowledge: Its Scope and Limits (London: Allen and Unwin, 1948), 507.

69 Russell, op. cit. note 65.

70 Bertrand Russell, The Autobiography of Bertrand Russell (London: Allen and Unwin, 1969), Vol. III, 223.

71 Newman, op. cit. note 55, 54-5. 


\section{The Four Points of the Compass}

logic of faith, whereby one accepts a word in its totality, as opposed to a distinct logic of what is here called doubt, whereby one accepts words conditionally, through reason, examining every step of an argument. He declared that without assent - in either of these forms - 'we have no intellectual moorings, and are at the mercy of impulses, fancies and wandering lights'. ${ }^{72}$ Doubt was a genuine part of philosophy but could not supply the certainty of faith.

Newman was influenced by Hume; and Russell, like most of us, could not get beyond Hume. Hume is still famous for his argument that induction cannot demonstrate the certainty of anything. The only way that induction can be defended is to claim that the certainty demanded by Hume was simply too great for induction to bear. ${ }^{73}$ But, as everyone knows, Hume was not himself a sceptic. 'To Hume it seemed madness to renounce the principles, the Principle of the Uniformity of Nature, for example, or the Law of Causality, simply because the fraudulence of all claims for their rational validity had been exposed. If such principles expressed logically unjustifiable assumptions, they also represented psychologically necessary ones for imposing order and intelligibility upon the world in which men have to think in order to survive. ${ }^{74}$ Hume was, in the end, a philosopher of doubt, content with relative certainties. He wanted a system 'which if not true (for that, perhaps is too much to be hop'd for) might at least be satisfactory to the human mind, and might stand the test of the most critical examination'. ${ }^{75}$

The greatest achievement of the philosophy of doubt may be the tradition of 'common sense' which comes down from Reid through Hamilton, Moore and Stove. Reid thought that philosophy 'has no other root but the principles of common sense'. We have to take them for granted; we can give no reason for them: and 'what is manifestly contrary to them, is what we call absurd'. It followed that if a man 'suffers himself to be reasoned out of the principles of common sense, by metaphysical arguments, we may call this metaphysical lunacy. ${ }^{76}$ Reid thought that the arguments of most

72 Ibid., 63.

73 See David Stove, Popper and After: Four Modern Irrationalists (Oxford: Pergamon, 1982), 56-84.

74 James Noxon, Hume's Philosophical Development: A Study of His Methods (Oxford: Clarendon Press, 1973), 10.

75 David Hume, A Treatise of Human Nature ed. L.A. Selby-Bigge (Oxford: Clarendon Press, 1888), 272.

76 Thomas Reid, An Inquiry into the Human Mind on the Principles of Common Sense ed. Derek Brookes (Edinburgh: Edinburgh University Press, 1997), 19, 33, 215-16, quoted in Nicholas Wolterstorff, 'Reid on 
philosophers from Plato to Hume naturally led to scepticism and 'the destruction to all science and common sense'. ${ }^{77} \mathrm{He}$ argued against it, interestingly, by claiming that philosophers often postulated unnecessary entities such as ideas. Doubtless our mind has its own activity, but it is worthless explaining that activity by adding another type of object, an idea, to the objects we are conscious of. Reid thought it was remarkable that the theory of ideas had 'been so universally received by philosophers, that it was thought to need no proof'. 'I cannot help thinking that the whole history of philosophy has never furnished an instance of an opinion so unanimously entertained by Philosophers upon so slight grounds.' 78 Stove was even more scathing about this argument, which is, he suggested, an argument which illegitimately argues from necessity to contingency. The argument that

We can know things only as they are known to us

Therefore

We cannot know things as they are in themselves ${ }^{79}$

is 'contemptible' because it claims that 'our knowledge is not real knowledge at all, because it is our knowledge'. 80 To Stove, an unrepentant philosopher of doubt, this proves that 'there is something fearfully wrong with typical philosophical theories' ${ }^{81}$ But if this is so, then doubt empties out philosophy completely by suggesting that there is no other experience but that of Babel. Philosophers are still divided on this question. Some say that philosophy should deal with the 'obvious' while others still maintain it should deal with the 'unobvious' ${ }^{82}$ But doubt has obvious problems with both the obvious and the unobvious.

Common Sense', in The Cambridge Companion to Thomas Reid (Cambridge: Cambridge University Press, 2004), 77, 85, 87.

77 Reid, Inquiry, 75, quoted in John Greco, 'Reid's Reply to the Skeptic', Cambridge Companion to Thomas Reid, 135.

Reid, Inquiry, 75, and Thomas Reid, Essays on the Intellectual Powers of Man ed. Derek Brookes (Edinburgh: Edinburgh University Press, 2002), 183-4, quoted in Greco, 'Reid's Reply', 140.

79 Stove, op. cit. note 8, 165.

80 Ibid., 161.

81 Ibid., xi.

82 For the 'obvious' see Bernard Williams, 'What Might Philosophy Become?', in op. cit. note 21, 200-23, at 213. For the 'unobvious' see Anthony Kenny, 'Philosophy States Only What Everyone Admits', From 
Doubt has greater achievements to show that any other form of philosophy, but they are achievements of relative not absolute certainty. They may only be so many towers of Babel. Wittgenstein in On Certainty admitted that it was difficult to distinguish 'I know' and 'I believe'. ${ }^{83} \mathrm{He}$ wondered whether, in the end, certainty might be nothing other than a 'tone of voice'. ${ }^{84}$ If it were so, then the judgement would have to be that doubt would only doubtfully be a point of the philosophical compass at all. And as soon as we doubt doubt we are led back to the stranger but more secure certainties of wonder and faith or on to that of scepticism.

\section{Scepticism}

The four points of the compass are distinct but there is obviously a logic to their arrangement. We encounter a world; then we encounter a word which explains the world but also divides it; then we attempt to overcome division by establishing a hierarchy of words; and, finally, we come to the judgement that words cannot be formed into a hierarchy: that, in fact, the only certainty about words (or the world) is that there is no certainty. This is scepticism, the fourth point of the compass. It is in a sense formally the same as doubt but it is doubt completed; and doubt completed is not doubt: for if doubt is completed then it doubts that there is certainty; whereas, as I have shown, it is the fundamental postulate of doubt that there is a certainty which can be established through some method or other. Here we alter direction completely: for although we are, in scepticism, still committed to rational argument, it has a different purpose. So far we have reached the boundary of rational argument, which is the telos of doubt: but the telos of scepticism is beyond this boundary. And so we go beyond diction to contradiction.

Doubt seeks the end of argument but scepticism seeks the end beyond argument. Doubt postulates certainty, scepticism does not. There is no better explanation of this than Hegel's.

We must not translate skepsis as 'doctrine of doubt' or 'seeking to doubt'. Scepticism is not a doubt, for doubt is the very opposite of the tranquillity that ought to be Scepticism's result. 'Doubt'

Empedocles to Wittgenstein: Historical Essays in Philosophy (Oxford: Clarendon Press, 2008), 136-48, at 143.

83 See Wittgenstein, op. cit. note 56, sect. 3, 2e and sect. 8, 3e.

84 Ibid., sect. 30, 6e. 


\section{James Alexander}

[Zweifel] derives from zwei; it is a vacillation between two or more points; a person settles upon neither the one nor the other and yet should settle upon one of the other, even though each is doubted... This standpoint of doubt is the opposite of Scepticism. Doubt is restless because it wants to find rest in something set in opposition to rest, and can find it nowhere. Scepticism, however, is equally indifferent to the one and to the other, and does not wish to find security in one of the opposed elements. This is Scepticism's standpoint of ataraxia. ${ }^{85}$

Doubt assumes that we can infer what is from what seems, and that there is a criterion of truth. Scepticism assumes that we cannot infer what is from what seems and that any criterion of truth requires, for its truth, a further criterion which leads us into an infinite regress and thus problems of fundamental contradiction. ${ }^{86}$ The only certainty in scepticism is the certainty - if it is a certainty - that certainty cannot be known. Doubt is not fully consistent, since it seeks a certainty it cannot find. And so scepticism completes doubt, by declaring that the principle of doubt must be applied to itself. But doubt cannot really deal with the paradoxes and contradictions encountered here. Doubt can only deal with a contradiction by solving it, or resolving it: that is, by translating it into something which is not a paradox but a mere doxa. But this usually fails. The fate of Frege's and Russell's mathematical logic is only the most recent testimony of this. Doubt dislikes paradox because a paradox is, in effect, a reductio ad absurdum. But scepticism, which does not postulate certainty, or unity of understanding, as its achievement, can consider that paradoxes and contradictions are constitutive of whatever truth there is to be had about words and world. So scepticism is a genuinely distinct point of the philosophical compass.

It is common now for writers to distinguish ancient and modern scepticism. ${ }^{87}$ But although some of the differences between them are interesting - especially the classical view that scepticism culminates in a way of life - they are all variants of an inclination to accept the paradoxes which come at the limits of thought. Zeno's

85 G.W.F. Hegel, Lectures on the History of Philosophy 1825-6 ed. Robert F. Brown, (Oxford: Clarendon Press, 2006), Vol. II, 307-08.

86 Diogenes Laertius, Lives of the Philosophers, 9.94, in the Loeb edition trans. R.D. Hicks (Camb. Mass.: Harvard University Press, 1965), Vol. II, 507.

87 See for instance Julia Anna and Jonathan Barnes, The Modes of Scepticism (Cambridge: Cambridge University Press, 1985). 
argument for the unreality of movement, Anselm's argument for the existence of God, Berkeley's argument for idealism, Mc'Taggart's argument for the unreality of time, are all masterpieces of sceptical thought. They are often taken to be paradigmatic of what philosophy is: but they are typical only of sceptical philosophy. They are all meditations on certainty: and tend to generate problems for us only if we want to establish certainty. Even Descartes' Meditations can be read as a study of paradox rather than a resolution of it. Santayana said that sceptics assume that 'all knowledge' is 'faith only': so that 'an existing world' is 'a questionable and arbitrary thing'. 88 The sceptic is willing to doubt that there is a world, or words, or anything. He agrees with Newman that doubt requires notional assent and can never command real assent, but then adds that real assent is beyond human capacity. So we have to recognise, as Oakeshott recognised, that 'all understandings are conditional'. 89 'The difference between modern and ancient scepticism is whether we think that our recognising this is a positive achievement or not. Moderns think it is not; ancients, like Pyrrho and Sextus, thought it was.

The greatest philosophers tended to suppose that scepticism is irrefutable - and that it simply has to be ignored, as Aristotle or Hume ignored it. Hegel locked scepticism into his system as an element of its dialectic. ${ }^{90}$ But most modern philosophers, committed to doubt, still find it necessary to refute or rebut scepticism. The usual way to refute scepticism is to say that it refutes itself. For instance, it is said that to claim 'There is no truth' is to claim 'The truth is that there is no truth', which is a contradiction. ${ }^{91}$ Or that to claim 'There is no truth' requires us to claim the equal and opposite belief 'There is a truth', which again is a contradiction. Grayling, in his Refutation of Scepticism, claims that 'scepticism is idle because we cannot help but believe in the existence of objects; ... this belief is so fundamental that it is senseless or futile to call it into question.' ${ }^{2}$ 'This does not sound like a refutation. And there is usually no reason to think scepticism has been refuted - because sceptics do not suppose that

88 Santayana, op. cit. note $29,49$.

89 Michael Oakeshott, On Human Conduct (Oxford: Clarendon Press, 1975), 98.

90 Kenneth R. Westphal, Hegel's Epistemological Realism: A Study of the Aim and Method of Hegel's Phenomenology of Spirit (Dordrecht: Kluwer Academic, 1989), 11.

91 Used by Stephen Clark in God's World and the Great Awakening (Oxford: Clarendon, 1991), 23.

92 A.C. Grayling, The Refutation of Scepticism (London: Duckworth, 1985), 77. 
contradiction is refutation. ${ }^{93}$ Arendt rightly recognized that "nobody who clings fast to the motion that "there is no truth", will ever be convinced if it is pointed out to him that the proposition is self-defeating' ${ }^{94}$ Most philosophers would now most likely agree with Strawson that Stroud was right to say that even a transcendental argument cannot refute scepticism and that, as Hume supposed, there are two different levels of thought, one which is concerned with absolutes, where scepticism is irrefutable, and one concerned with relatives, where scepticism is irrelevant. ${ }^{95}$ But even Sextus or Nagarjuna would have agreed with this. They never supposed that scepticism denied the existence of Babel.

Scepticism is far from simple. It may range from the extremes where we say 'nothing is true' or 'everything is true' to a complete logic of scepticism according to which questions about ultimates, absolutes, or universals are answered by saying that everything is, is not, both is and is not, and neither is nor is not. ${ }^{96}$ This logical form, the tetralemma, is first mentioned in our tradition in relation to the teaching of Pyrrho, the founder of scepticism.

[Pyrrho] reveals that things are equally indifferent and unstable and indeterminate: for this reason neither our sensations nor our opinions tell the truth or lie. For this reason, then, we should not trust them, but should be without opinions and without inclinations and without wavering, saying about each single thing that it no more is than is not or both is and is not or neithers nor is not. ${ }^{97}$

93 For the most elaborate exploration of why this is so see Luca Castagnoli, Ancient Self-Refutation: The Logic and History of the Self-Refutation Argument from Democritus to Augustine (Cambridge: Cambridge University Press, 2010), esp. 307-07. The only philosopher I have read who does consider the scepticism in all its subtlety and yet considers it fails is Graham Priest, Beyond the Limits of Thought $2^{\text {nd }}$ ed. (Oxford: Clarendon Press, 2002), 42-55.

94 Arendt, op. cit. note 7, 149-50.

95 See P.F. Strawson, Scepticism and Naturalism: Some Varieties (London: Methuen, 1985). See also Barry Stroud, The Significance of Philosophical Scepticism (Oxford: Clarendon Press, 1984).

96 See Priest, who calls these respectively 'scepticism' ('nothing is true'), 'trivialism' ('everything is true'), and 'dialethism': which last is his word for his own doctrine that our usual philosophy of doubt breaks down at the limits of thought. Priest is doubtful whether anyone has subscribed to 'trivialism'. He suggests perhaps Anaxagoras did, and adds that Aristotle thought Heraclitus and Protagoras did. See Priest, op. cit. note 93, 12 \& 65.

97 Eusebius, quoting Aristocles, quoting Timon, in Richard Bett, Pyrrho, His Antecedents and His Legacy (Oxford: Oxford University Press, 2000), 16. 
There are two possible interpretations here: either Pyrrho advocated a subjective scepticism - where one is sceptical of words since one supposes they say nothing certain about the world - or an objective scepticism - where one is sceptical about the truth of any word about the world because the world is itself paradoxical so that 'it is, is not, both is and is not, and neither is nor is not' ${ }^{98}$ 'The former is only logical, the latter ontological. Some sceptics, like Sextus, thought it very important to distinguish the two. But it seems here that in the end whether scepticism is about words or about the world makes no difference: the oscillation is part of the paradox embraced by scepticism.

According to Sextus, the sceptics were to be distinguished not only from the philosophers who dogmatically established truth, but also from those who dogmatically claimed that truth could not be established. Scepticism was thus dynamic rather than static. It refused to establish its truths as dogma. This perhaps makes no difference, if the sceptical judgement is always in effect the same as if it were dogmatic - especially since opponents of scepticism tend to argue it $i s$ dogmatic. ${ }^{99}$ But it was coherent. Sextus saw that if nothing can be known, then it cannot be known that nothing can be known. But he was willing to sacrifice all argument if necessary. He declared that a bad argument would do as well as a good one for his purposes. ${ }^{100}$ And he declared that an argument, when used by a sceptic, was not an argument. ${ }^{101}$ Which, of course, are maddening arguments (or whatever they are) for any philosopher committed to doubt. Williams thought that sceptics were not philosophers at all. 'Ataraxia followed, for the Pyrrhonists, not on answering fundamental questions, but on being induced to give up answering them.' 102

The sceptical method as Sextus outlined it was simple, although capable of endless subtlety. It was a method of 'opposing to every

98 See ibid., 32.

99 Hegel, Lectures on the History of Philosophy, Vol. II, 294, 306. Diogenes Laertius, op. cit. note 86, 9.102, Vol. II, 513.

100 Sextus Empiricus, Outlines of Pyrrhonism 3.281, in the Loeb edition trans. R.G. Bury (Camb. Mass.: Harvard University Press, 1933), 513.

101 'When we state ... the probable arguments for the non-existence of the criterion that occur to us, we do indeed state them, but when we do this we do not add our assent, owing to the fact that the contrary arguments are equally probable.' Sextus Empiricus, Against the Logicians, 1.444, in the Loeb edition trans. R.G. Bury (Camb. Mass.: Harvard University Press, 1935), 239.

102 Williams, op. cit. note $28,33$. 
proposition an equal proposition'. ${ }^{103}$ If it could be demonstrated that any proposition and its opposite were of equal value, then there was no proposition so certain which would not have an opposite equally certain - that is, not certain at all. If this was so, then there was no certainty except the certainty of uncertainty (although Sextus, as we have seen, tried to avoid putting it this way). The stated purpose of the sceptics was to achieve, through a suspension of judgement they called epoché, a state of quietude or imperturbability they called ataraxia. ${ }^{104}$ Santayana seemed to think that scepticism would dissolve words and take us around the compass to something like wonder. 'The most radical sceptic may be consoled, without being rebuked or refuted; he may leap at one bound over the whole human tangle of beliefs and dogmatic claims, elude human incapacity and bias, and take hold of the quite sufficient assurance that any essence of ideal quality of being which he may be intuiting has just the character he is finding in it, and has them eternally.' 105

Scepticism is endlessly ambiguous: because what sceptics are certain of is uncertainty and what they are uncertain of is certainty. 'Properly speaking', Hegel declared, 'it cannot be refuted'. ${ }^{106}$ Hegel was perhaps the first in our tradition to recognise that contradictions are true:

According to Kant, thought has a natural tendency to issue in contradictions or antinomies, whenever it seems to apprehend the infinite. But Kant ... never penetrated to the discovery of what the antinomies really and positively mean. The true and positive meaning of the antinomies is this: that every actual thing involves a coexistence of opposed elements... ${ }^{107}$

Scepticism involves the view that human reason breaks down under extreme conditions - and, in addition, that this fact is a fact of permanent relevance to reason even when we are not reasoning at the limit.

103 Sextus Empiricus, op. cit. note 100, 1.12, 9.

104 Ibid., 1.11, 9. See the summary in Myles Burnyeat, 'Can the Sceptic Live with his Scepticism?', Doubt and Dogmatism: Studies in Hellenistic Epistemology ed. Malcolm Schofield, Myles Burnyeat, Jonathan Barnes (Oxford: Clarendon Press, 1980), 20-53, at 24-5.

105 Santayana, op. cit. note $29,75$.

106 G.W.F. Hegel, Lectures on the History of Philosophy trans. E.S. Haldane \& F.H. Simson (London: Kegan, Paul, Trench and Trübner, 1892-96), Vol. II, 329. There is no equivalent of this line in the recent edition of the 1825-6 lectures.

107 Hegel, Lesser Logic, 48, quoted in Priest, In Contradiction: A Study of the Transconsistent $2^{\text {nd }}$ ed. (Oxford: Clarendon Press, 2006), 1. 


\section{The Four Points of the Compass}

So scepticism has a more capacious logic than doubt. Priest has reminded us that

given two states of affairs, there are, in general, four possibilities: one but not the other holds, vice versa, both or neither. In particular, given the states of affairs $\alpha$ is true and $\alpha$ is false there are, without begging any questions, those four possibilities. But the standard logical theory just assumes that only two of them should be allowed for. Slightly more liberal views allow that a third may arise, the neither case. ${ }^{108}$

But it is the full tetralemma-or, in Sanskrit, catuhskoti-which is the fundamental structure of all exhaustive arguments. Although the standard laws of logic apply in relation to 'finitude', they do not explain the infinite, the ultimate, the absolute. In such cases the laws of identity, contradiction, etc., break down. Then we require a logic which embraces paradox: because only such a logic can explain claims of the form that there is 'a totality $\Omega$, and an object, $\mathrm{o}$, such that $\mathrm{o}$ is and is not in $\Omega{ }^{\prime}{ }^{109}$

We find this sort of claim in the Mulamadhyamikakarika of Nagarjuna, who argued that the ultimate truth is that there is no ultimate truth. The ultimate truth, o, of the world, $\Omega$, is that 'everything is empty', but if this is true then it is both transcendently and immanently true: that is, in so far as it refers to conventional truths it is true, but in so far as it refers to its own truth, it establishes its own emptiness, and is neither true nor false. ${ }^{110}$ The 'emptiness' which seems to be the telos of scepticism is distinctive. For whereas wonder, faith and doubt all postulate a one which is a one, scepticism seems to postulate a one which is a nought and is nonetheless a one. Words dissolve, and the correlative is that the world itself dissolves. And yet both words and worlds remain. 'The one and the same reality when viewed through the category of cause and condition is called the world, and when the causes and conditions are disregarded it is called nirvana.'111

108 Priest, op. cit. note $93,4$.

109 Ibid., 252. For the opposite claim that the laws of logic have not begun to work yet since they are not of this world, see S.R.L. Clark, 'Deconstructing the Laws of Logic', Philosophy 83 (2008), 25-53.

110 See the discussion of Nagarjuna's logic in Priest, op. cit. note 93, 263-69.

111 Nagarjuna, Mulamadhyamikakarika, 25.9, quoted in Dilip Kumar Mohanta, Cognitive Scepticism and Indian Philosophy (Calcutta: Punthi Pustak, 1999), 19. 


\section{James Alexander}

Through suspension of belief, for Sextus, we achieve ataraxia, which is both radical denial and radical acceptance of the world. And for Nagarjuna, we achieve a nirvana which is no more and no less, paradoxically, than samsara.

The major problem with scepticism is that it is unanswerable in such a way that it may seem to be a negative replication of faith, an absolute negation, just as faith is an absolute position. But unlike faith, it leaves the world undisturbed by words.

\section{Conclusion}

This has been a short but, I hope, original attempt to see philosophy in its entirety. It may seem quixotic, or eccentric, a making of arbitrary patterns. But it is not. It is the objective embodiment of a sense that philosophy should not be narrowed to something which occurs within Fregean or Wittgensteinian or Popperian boundaries. If 'philosophy' stands for only the non-quantitative application of methods of doubt to the world then so be it: in which case we will have to find a new word for the compass which, I have argued here, has wonder, faith, doubt and scepticism at its four points. Philosophy is a good word for this compass; but another word could be found if philosophy would no longer do.

The four points of the philosophical compass are:

i. that there is a world and no words to explain it, so that words and world are part of one undifferentiated reality - and our response is wonder;

ii. that there is a world, and one word to explain it, which is not itself of this world, and so explains it on authority - and our response is faith;

iii. that there is a world, and many words which appear to explain it, which we, by some method or other, must examine to establish the certainty we suppose is there and our response is doubt;

iv. that there is a world, or worlds, and many words which appear to explain it, or them, none of which have any greater authority or reason or status than any other, so that we are left with uncertainty - and so our response is scepticism.

As long as we experience wonder, faith, doubt and scepticism we will have philosophers among us. Nietzsche's remarkable 'history of an error' in Twilight of the Idols is the story of one man venturing 
through wonder to faith to doubt to scepticism. ${ }^{112}$ But there is no 'incipit Zarathustra' here because I would not suggest that there is a necessary progression, except logically: and it is likely, anyhow, that anyone who ventured through all four would return to the beginning again. Each point seeks an unbroken unity, or certainty, although each differs about where certainty is to be found. The world is certainty about itself; or a word is the certainty of the world; or one word of many is shown to be the certainty of the world; or words establish only that words cannot express the certainty of the world. But there is nothing necessary about how any philosopher marks his own compass.

History indicates that all four have been taken seriously at almost all times. But modern academic philosophy, as it has become established since Descartes, has tended to emphasise the superiority of doubt. Doubt is delusive: for, when taken alone, it has difficulty demonstrating the certainties it postulates as necessary. The other three points of the compass achieve the certainties they offer because their certainties are strange certainties: the silent certainty of wonder, the absurd certainty of faith or the paradoxical certainty of scepticism. So the philosopher, if his compass is marked only with doubt, may soon find himself back in Babel.

Bilkent University, Ankara jalexand@bilkent.edu.tr

112 Friedrich Nietzsche, Twilight of the Idols and The Anti-Christ trans. R.J. Hollingdale (Harmondsworth: Penguin, 1968), 40-1. 